\title{
En flytning i "Vinterens Hjerte"
}

Det gik ikke ubemarket hen blandt københavnerne midt i julemaineden 1937, at der $i$ kvarteret omkring Krystalgade og Fiolstrede, dvs. i Latinerkvarterets gader omkring Universitetsbiblioteket, lod en klasken og banken fra boger, der blev renset og støvet af inden de blev pakket $i$ kasser, for siden at blive kort med flytteomnibusser med anhangere til Norre Falled.

aflektor, cand.mag. \& phil. \& cand.scient.bibl. Martin Dyrbye, Det Informationsvidenskabelige Akademi, Kbh. Universitet

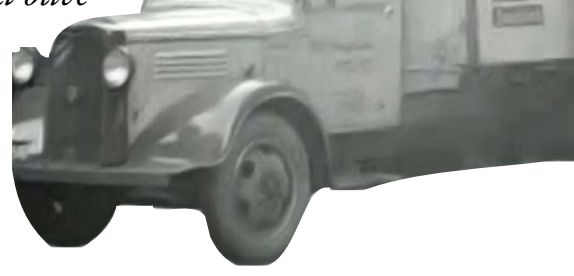

$\mathrm{F}$ or 75 år siden fandt en overordentlig vigtig begivenhed sted i dansk videnskabs historie, da Universitetsbiblioteket i Fiolstræde under Københavns Universitet blev delt i to afdelinger, og den humanistiske litteratur blev adskilt fra den naturvidenskabelige og medicinske, der blev flyttet til et helt nyt bibliotek på Nørre Fælled i nær tilknytning til Universitetsparkens institutter og institutioner - ikke ulig en såkaldt campus. Det nye universitetsbibliotek, altså Universitetsbibliotekets 2. Afdeling, slog dørene op for publikum den 10. februar $1938 \mathrm{i}$ Nørre Allé.

Fra den 13. december 1937 og i de følgende to måneder fandt en af de helt store udskillelser og flytninger sted af en - set med samtidens øjne - kolossal "bogmasse", eller "vidensbank" om man vil, hvilket vakte en berettiget opsigt både i skriftlige medier, altså aviser, blade og tidsskrifter, og i den æterbårne radio i form af et interview i Statsradiofoniens Pressens Radioavis i 1938, ${ }^{1}$ og til overflod blev flytningen dokumenteret i en lille reportagefilm, som blev vist i en af de populære ugerevyer i biografteatrene.
En fremstilling af begivenhederne dengang giver os også anledning til at mindes en række danske biblioteksfolks fremsynethed, da de i lyset af videnskabens udvikling fik gennemtrumfet opførelsen af den nye biblioteksbygning og samtidig skabt en ny ramme for naturvidenskabernes og medicinens vidensorganisation ved en nyopstilling af bogmassen. Den var i hastig vækst, og det nye bibliotek med dets bogtårn konstrueredes på en sådan måde, at der kunne være plads til en fordobling af antallet af bøger og tidsskrifter fra godt 200.000 til 400.000 enheder, eller svarende til godt og vel 12 hyldekilometer.

\section{Udskillelse og flytning af bogmassen}

Etableringen af et helt nyt og moderne forskningsbibliotek, et nyt vidensrum for naturvidenskab og medicin - i samtiden opfattet som en del af "Videnskabens Værksted" - må ses i lyset af den rivende udvikling, de nævnte fagområder havde oplevet internationalt og nationalt med en kolossal vækst i antallet af publikationer. Trods landets lidenhed lå Danmark højt placeret inden for en række 
fagområder, f.eks. inden for teknikken og ingeniørvidenskaben, og for naturvidenskabens og medicinens vedkommende kunne nationen bryste sig af at have bidraget med hele fire nobelpristagere i perioden 1903-1926 inden for de fagområder, som det nye bibliotek skulle dække.

Tilvæksten i litteraturen inden for naturvidenskaberne og medicin på Universitetsbiblioteket og etableringen af nye vidensrum, deriblandt flere naturog lægevidenskabelige institutter under Københavns Universitet på Nørre Fælled i det kvarter, som senere benævntes Universitetsparken, betød, at placeringen af faglitteraturen måtte ændres geografisk. Det nye universitetsbibliotek i nærheden skulle tilgodese ønsker om lettere fysisk adgang til bogmassen, forbedrede læsesalsmuligheder og f.eks. også muligheder for at kunne gøre brug af samtidens fotokopieringsteknik m.m. Adgangen til informationer blev betydeligt lettet for de primære lånere, altså forskere og studerende ved universitetet. En deling af det eksisterende universitetsbibliotek betød også en rationalisering og effektivisering, som på længere sigt var til gavn for alle de benyttere, herunder også udenbys lånere rundt omkring i landet, der også havde brug for litteratur inden for natur- og lægevidenskaben.

I de sidste måneder af 1937 var byggeriet af det nye universitetsbibliotek så langt fremskredet, at den fysiske flytning af bogmassen fra Fiolstræde til Nørre Allé kunne begynde. Forud herfor var gået en langvarig proces, hvor Universitetsbibliotekets overbibliotekar, Svend Dahl, sekunderet af bibliotekarerne Luplau Jannsen og Frederik Høyer samt det øvrige personale, nøje havde foretaget beregninger, opmålinger, gennemgange af bestan- den og indhentet tilbud på den fysiske flytning. Der var blandt de københavnske flyttefirmaer naturligvis stor interesse for opgaven, og fra begyndelsen af 1930'erne og frem til efteråret 1937 kom flere henvendelser. Det blev imidlertid Transport Danmark, som fik den prestigefyldte ordre, efter at tilbudsgivningen var overstået. Samarbejdet mellem bibliotekets personale og firmaets flyttefolk fungerede godt, og efter flytningen modtog Transport Danmark et fornemt diplom med universitetsbibliotekets anbefaling.

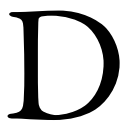
en praktiske tilrettelæggelse af udskillelsen af bøger og tidsskrifter samt flytningen påbegyndtes i begyndelsen af januar 1937, altså godt et år før indvielsen af det nye universitetsbibliotek. Tre samtidige kilder giver et godt indtryk af, hvorledes opgaven med flytningen blev løst, og det er på baggrund af dette kildemateriale, at den følgende fremstilling bygger:

For det første har overbibliotekar Svend Dahl i en artikel i det første nummer af Bogens Verden fra 1938 nøje beskrevet processen vedrørende forarbejderne, mens hans medarbejder, bibliotekar Alfred Høyer sluttede deres fælles bidrag med en skildring af selve flytningen. ${ }^{2}$

For det andet blev der under flytningen optaget en lille filmsekvens på 1 minut og 11 sekunder til Dansk Film Revy bragt som forfilm i biograferne med overskriften "7 km. Bøger flyttes": Speakeren forklarer, hvad der sker på billederne og indledningsvis ses overbibliotekar Svend Dahl, der ledede flytningen, og bibliotekar Luplau Janssen samtale, mens de ser på en model af det nye bibliotek og ifølge speakeren "drøfter planerne for overflytningen af Universitetsbibliotekets medi- 


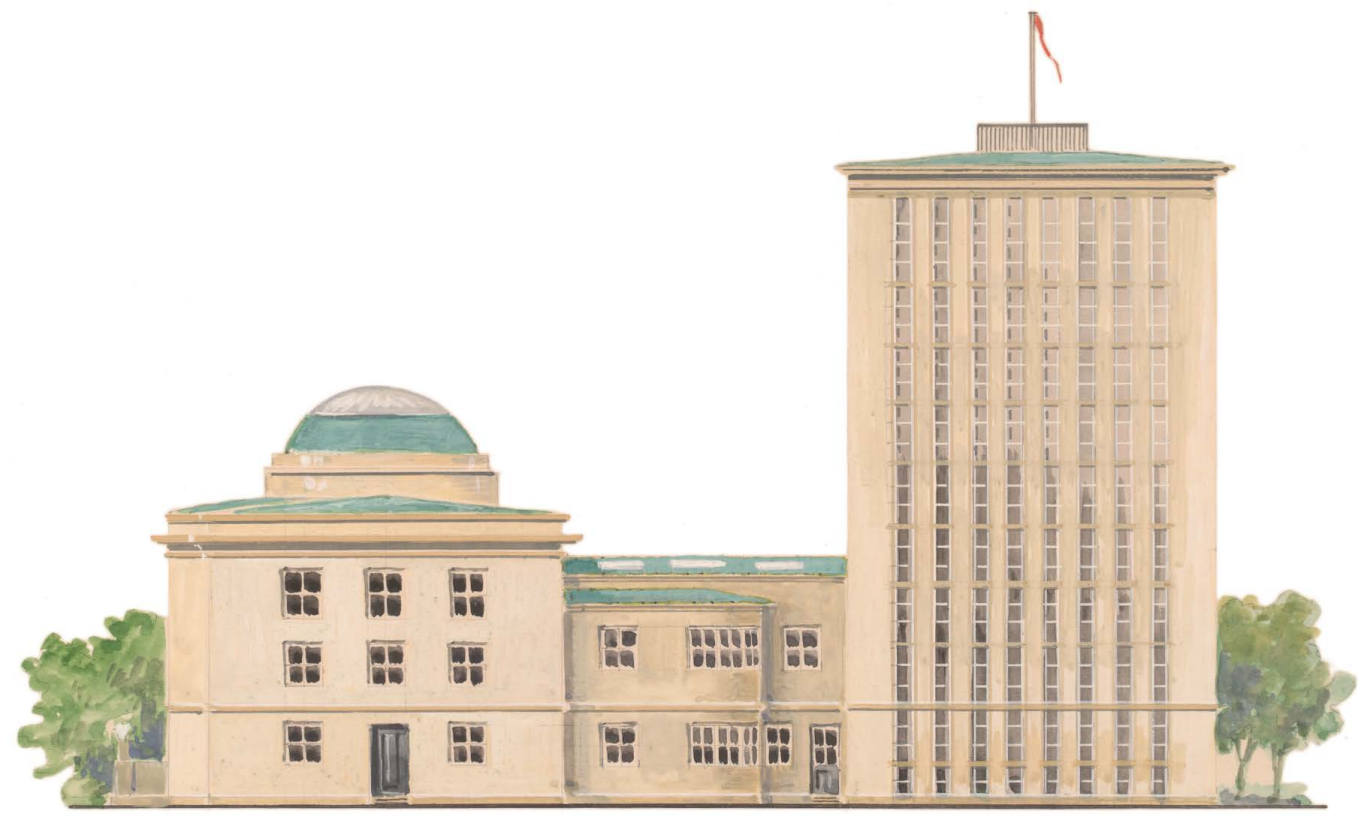

Akvarel af Hakon Spliid fra 1934, dvs. på baggrund af arkitekttegninger. Bogtårnets vinduer adskiller sig noget fra det endelige resultat.

cinske, naturvidenskabelige Samling" til Nørre Fælled.

Og for det tredje suppleres disse to kilder af et radiointerview: Til journalisten Bent Demer fra Pressens Radioavis fortalte Svend Dahl, der var "kommet til Mikrofonen", begejstret om "hvordan man flytter $6 \mathrm{~km}$ Bøger". Det vides ikke præcis, hvornår interviewet blev bragt, men efter indholdet at dømme tyder det på at være sket kort før åbningen i februar 1938. Journalisten havde et godt blik for med ord at karakterisere det nye biblioteks placering for lytterne: "Ude paa Hjørnet af Tagensvej og Nørre Allé, paa det Hjørne af Nørre Fælled, hvor i gamle Dage den lille Lammesø laa, er den nye Bygning for Universitetsbibliotekets natur- og lægevidenskabelige Del skudt op af Jorden som et andet Aladdins Palads og er allerede nu gledet ind i Gadebilledet med sit imponerende Bogtaarn og sine smukke, stilrene Kalkstensfacader."
$\mathrm{I}$ interviewet, som i dag alene findes bevaret gennem en samtidig udskrift på godt ni maskinskrevne sider, berettede Dahl om flytningen og de gener, som den måtte betyde for "Folk, der sidder midt i et videnskabeligt Arbejde og har haardt Brug for vore Bøger" ved en lukning på over $1 \frac{1}{2}$ måned, men - tilføjede overbibliotekaren nøgternt: "Folk, der selv har prøvet, hvor besværligt det kan være at flytte en lille privat Bogsamling, vil vist snarest synes, at halvanden Maaned ikke er lang Tid til Flytning og Opstilling af henimod 200.000 Bind, saadan som det drejer sig om her." Der var tale om en "hurtig Præstation".

\section{Udfordringen ved at flytte et bibliotek}

Det var ikke første gang i Danmarkshistorien, at en større biblioteksflytning skulle finde sted, og Dahl nævnte både i radioen og $\mathrm{i}$ artiklen i Bogens Verden, hvilke overvejelser man gjorde 
sig herom: "Det vilde paa Forhaand være rimeligt at undersøge, om der fra tidligere Biblioteksflytninger herhjemme eller andetsteds kunde hentes Erfaringer, der kunde faa Betydning for os. Af Universitetsbibliotekets egen Flytning i 1861 fra Trinitatis Kirkes Loft til Fiolstræde, da Bøgerne i Løbet af et halvt Aars Tid blev baaret i flade Kasser ned gennem Rundetaarns Sneglegang og paa Møbelvogne trukket af to Karle gennem Kannikestræde, kunde intet læres, og heller ikke Det kgl. Biblioteks store Flytning i 1906, da Bøgerne ad en interimistisk Bro blev kørt fra den gamle til den nye Bygning, kunne være synderligt vejledende - Dertil var forholdene for forskellige". Heller ikke erfaringer fra udlandet kunne umiddelbart overføres til den konkrete flytning, idet der var tale om "mange særlige Forhold" og "saa store og ekstraordinære Vanskeligheder, at man kun i ringe Grad kunde lære af Forbilleder andetsteds."

Den store udfordring var ifølge Dahl, at opstillingen af "Bogbestanden" ville være en helt anden i den nye bygning, og "ved den nye Opstilling vilde man udelukkende lade sig lede af Hensynet til det rent praktiske: at faa de mest benyttede Afdelinger anbragt saa nær Ekspeditionen som muligt, og derfor vilde man bl.a. sammenstille alle tidsskrifter til en særlig, alfabetisk ordnet Tidsskriftafdeling og skille Litteraturen før og efter 1900 ud fra hinanden." Imidlertid voldte princippet om en nyordning forud for flytningen "den vanskelighed, at hele den Bogmasse, som skulde flyttes, i Forvejen maatte opstilles i den gamle Bygning”. Det medførte pladsproblemer, men alligevel lykkedes det successivt at få bøgerne lagt op på borde i midten af bogsalen og folianter på montrer "efterhaanden som Flytningen skred frem". Det betød til gengæld, at det var "umuligt paa Forhaand at udarbejde detaillerede Skemaer over Opstillingen, saaledes som man ellers naturligt vilde gøre", og - tilføjede Dahl: "man maatte i den nye Bygnings 10 Etagers Bogtaarn hænge Staalhylderne op efter et Skøn og kunde ikke engang paa forhaand faa en blot nogenlunde nøjagtig Opgørelse over, hvor meget Bøgerne før og efter 1900 fyldte i Meter." Derimod kunne en udmåling godt lade sig gøre for tidsskrifternes vedkommende, "over hvilke der i Forvejen var blevet udarbejdet et Seddelkatalog". På hver seddel var nemlig angivet, "hvor meget det fyldte, og hvor meget 20 Aars tilvækst kunde antages at fylde".

\section{Den midlertidige lukning af Universi- tetsbiblioteket i Fiolstræe de}

Det var naturligvis ikke uproblematisk at lukke et universitetsbibliotek $\mathrm{i}$ hen ved to måneder. Biblioteket havde gennem et længere forarbejde gjort sit til at optimere selve flytningen, så antallet af lukkedage reduceredes mest muligt. Bibliotekets lånere, kontakter og samarbejdspartnere skulle have besked om, hvordan de skulle forholde sig i forbindelse med lukningen og genåbningen efter etableringen af de to fremtidige afdelinger $i$ henholdsvis Fiolstræde og Nørre Allé.

Der var også hensyn at tage overfor det daglige rutinearbejde, som også skulle passes, med indkøb, accession og katalogiseringsarbejde, men udlånets lukning betød, at opgaven kunne løses med relativt få omkostninger til øgede personaleudgifter. Med henvisning til, at Det Kongelige Biblioteks personale i forbindelse med dets flytning i 1906 havde fåt bevilget en særlig sum til overarbejdsbetaling, blev 
der også i dette tilfælde givet en ekstra bevilling til dette formål.

Fra lånernes side modtog biblioteket ikke nogle beklagelser på skrift over lukningen. En kernelåner gav derimod udtryk for forståelse og skrev på den sidste dag, lørdag den 11. december 1937 , hvor det endnu udelte Universitetsbibliotek i Fiolstræde var åbent for publikum følgende:

\section{“Til d'Herrer og Damer, som drager bort.}

Undertegnede, som i en længere Aaarække har besøgt Univ.Bibl., vil gærne herved udtale min bedste Tak for den store Imødekommenhed og Elskværdighed, som jeg stadig har mødt her paa Bibliotheket.

Jeg beder Dem Hr. Dumreicher ${ }^{4}$ om at bringe ovenstaaende til de bortdragendes Kundskab.

\section{Med venlig Hilsen \\ Deres heng. W. Schoustrup"}

Kort før lukketid skrev en af bibliotekets medarbejdere en kort besked til Svend Dahl med følgende ordlyd:

"Jeg antager, at det maaske vil interessere Dem at faa en Indberetning om, at alt er gaaet uhyre stilfærdigt og uden nogen som helst Uregelmæssigheder den sidste Aften - og nu lukker vi Lørd. den 11/12 37 Kl. 21.50”.

Herefter var Universitetsbibliotekets tid som én samlet enhed for Københavns Universitets mange forskellige fagområder inden for humaniora, naturvidenskaberne og medicin under ét og samme tag i Fiolstræde ved at rinde ud. I de følgende godt to måneder iværksattes den længe ventede flytning, og tiden ville vise, hvorvidt planer og beregninger forud herfor ville holde stik.

\section{Flytteplanerne og deres udmøntning i virkeligheden}

I sommeren 1937 forelå en meget detaljeret maskinskrevet plan for udførelsen af flytningen som sådan, forfattet af Alfred Høyer. Alle bøger skulle renses og aftørres for støv, hvilket skulle foregå på et centralt sted forud for nedpakningen $i$ flyttekasser og med lettest mulig adgang for flyttevognene. Dette fremgår også af ugerevyen, men skildres tillige i radioavisen, hvor Svend Dahl fortalte intervieweren Bent Demer ret detailleret om støv og bøger. Sidstnævnte udbrød nysgerrigt: "De sagde, at Bøgerne blev banket. Er det virkelig nødvendigt?", hvortil Dahl svarede: "Ja, Støvet er jo en af Bøgernes værste Fjender. Bogormene, som man i gamle Dage regnede for Bøgernes Fjende Nr. 1, ser vi nu saa godt som aldrig mere - undtagen dem i overført Betydning, og de gør jo ikke Bøgerne Fortræd. En anden Fjende var Gassen, men heller ikke den behøver vi at regne med mere. Støvet har vi derimod stadig at slaaes med, og det er egentlig utroligt, saa hurtigt selv Bøger, der benyttes tit, bliver støvet." Overbibliotekaren forsikrede desuden lytterne om, at der skam blev støvsuget "Aaret rundt", og tilføjede: "men den helt gennemgribende Rensning kan kun opnaas ved den gammeldags Bankning; her kan man virkelig faa alt det Støv, der gemmer sig i Bøgerne, ud af dem, og Flytningen frembyder jo en enestaaende Lejlighed til at faa en saadan Bankning udført. Hvis Folk, der i den sidste Maaneds Tid har passeret Krystalgade, 
har undret sig over den stadige Klasken, man hører fra Gaarden mellem zoologisk Museum og Biblioteket, saa véd de nu, hvad den kommer af. Naturligvis maa Bankningen foretages med Omhu, saa Bindene ikke beskadiges, men gør man det ordentligt, er Metoden absolut den bedste, man har."

Desuden forsikrede Dahl lytterne om, at bogtårnet i Nørre Allé var gjort "saa støvtæt som muligt, og ingen ringere end Professor August Krogh har været vor Konsulent paa dette Omraade". Den berømte fysiolog og nobelpristager havde, ifølge hans datters erindringsbog om faderens indretning af laboratoriet $i$ 1928 på Det fysiologiske Institut, også kaldet Rockefeller Instituttet, fundet på et princip, der kunne holde lokaler støvfri, men "på grund af forskellige fejl (blandt andet blev der anvendt forkerte materialer) kom det ikke helt til at fungere". Men senere blev "hans princip anvendt med held i det nye universitetsbibliotek...." Dette blev også fremhævet i reportagefilmen, hvor speakeren nævner, at den nye bygning er indrettet med "overtryk på luften, så støvet derved ikke kommer ind ad vinduerne".

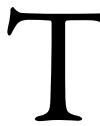
ilbage i Fiolstræde blev to vinduer i bogsalens facade ud mod gården ved Zoologisk Museum fjernet, og "omdannedes til Døre, der førte lige ud til et Træskur $(4 \times 6 \mathrm{~m})$ ", og - berettede Dahl: "i hver Side af dette skulde anbringes et Bord og et Vindue, gennem hvilket Bøgerne kunne bankes mod hinanden. Flyttevognen skulde kunne køre lige til Skurets dør, saa at Bogkasserne fra Skuret ad en Sliske kunne kure lige ind i Vognen." Det betød i praksis, at flyttevognene ikke behøvede at optage plads i det trafikerede
Fiolstræde, og flytningen kunne derved "foregaa ganske ugenert." Denne del af operationen blev også skildret i reportagefilmen.

Planen, som blev fulgt under selve flytningen indeholdt oplysninger om opstilling af midlertidige borde i bogsalen og skemaer over den forventede opstilling i den nye bygning, antal dage beregnet til "de enkelte Gruppers Flytning" med en varighed fra medio december 1937 og frem til begyndelsen af februar 1938 .

Beregningsarbejdet forud for opstillingen udførtes ligeledes af bibliotekar Alfred Høyer, der også stod for overvågningen af flytningen i det daglige arbejde, bistået af 17 medarbejdere, dvs. bibliotekarer, assistenter, deriblandt den senere rigsbibliotekar, Palle Birkelund, og betjente. Foruden selve arbejdet med flytningen skulle en række andre opgaver løses "af lige saa stor Betydning for Bibliotekets Deling", og - anførte overbibliotekaren: "ved disse Arbejder har den øvrige Del af Bibliotekets Personale været beskæftiget baade forud for og under Flytningen".

I sin beretning om flytningen anførte Alfred Høyer, at bogmassen, der skulle flyttes, "androg ca. $61 / 2 \mathrm{~km}$ eller henved $180.000 \mathrm{Bd}$. og et lignende Antal uindbundne Disputatser" indenfor hovedfagene medicin, matematik, naturvidenskaberne, samt "anvendt Naturvidenskab (Teknologi, Landbrug, Jagt etc.), og dertil kom udtagning "af de Afdelinger, som blev tilbage i den gamle Bygning" et antal på ca. 6.000 bind af "særlig natur- eller lægevidenskabelig Interesse."

Arbejdet med den fysiske flytning af dagligt godt 5.000 bind fandt sted fra kl. 8, altså før daggry, og frem til kl. 16.30, altså i mørkningen lige efter solnedgang. Den 13. december 1937 var biblioteket 
lukket. Næste dag "mødte Flytteomnibusserne og begyndte at køre”. Som ekstra hjælp blev antaget " 4 Mand til Hjælp ved det manuelle Arbejde". Der blev i starten arbejdet med to hold i skuret, men - tilføjede Høyer i sin beretning om flytningen - så "viste det sig efterhånden, at dette ikke forøgede Hastigheden i tilstrækkelig grad og desuden vanskeliggjorde Opstillingen i det nye Hus, øgede Muligheden for Fejl og krævede mere Personale, saa at de, der var beskæftiget med Fremtagning af Bøger, ikke kunne fodre de graadige Bogkasser i det fornødne Tempo, og man gik derfor over til kun at arbejde med eet Sæt Afsendelser" ${ }^{6}$

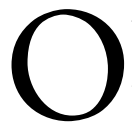
venstånde beretning suppleres på glimrende vis også af ugerevyens reportage, hvor den fysiske flytning af bogmassen fra Fiolstræde til Nørre Allé skildres i ord og levende billeder: I vinduet i det gamle universitetsbibliotek står to ansatte, som er i færd med at rense og banke bøgerne fri for støv, før de flyttes i store kasser ned til det interimistiske træskur. Derfra bæres de ind i flytteomnibussen, vogn "No. 5" med anhænger fra flyttefirmaet Transport Danmark. Ifølge speakeren, som har lagt lidt ekstra tal til historien, var der tale om en flytning af "ikke mindre end 300.000 bind, eller $7 \mathrm{~km}$ ", som "i løbet af 2 måneder" blev "overført til de nye bygninger", hvis facader ses afbildet på filmen. Fokus rettes herefter særligt mod det for sin tid imponerende nye bibliotek og bogtårnet med dets i alt 10 etager. På 9. etage ses fire ansatte, som ser ud af tre åbentstående vinduer. Speakeren fortæller, at bogtårnet senere kan øges med "endnu flere" etager. Herefter ses flyttefolk, der bærer trækasser med bøger fra flyttebilen hen til

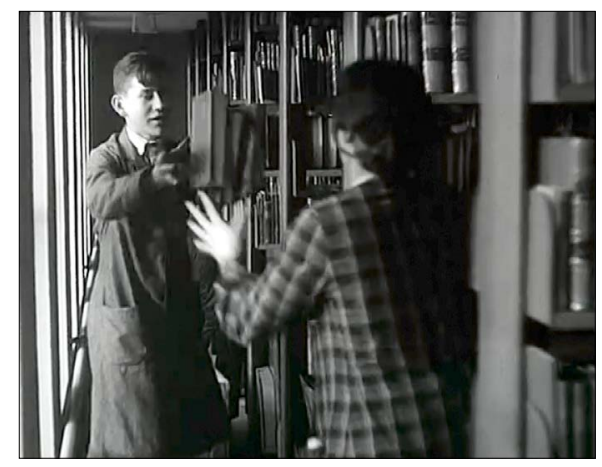

Bogkast. Still-billede fra reportagefilmen, som kan ses på <www.danskkulturarv.dk/dr/nytmedicinsk-bibliotek $>$. Eller scan her:

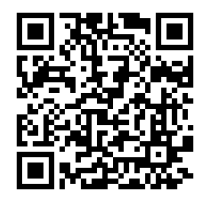

biblioteksfolkene, som står klar til at tage imod den store bogmasse. Bøgerne flyttes tre og tre med lette håndkast i en kæde af medarbejdere og sættes så på deres plads $\mathrm{i}$ det moderne reolsystem. I filmens sidste sekvenser vises billeder af hovedbygningens imponerende kuppel set fra luften, med "Zeiss prismer, der lader dagslyset uhindret trænge igennem", alt imens biler og cykler kører neden for på gaden og $\mathrm{i}$ rundkørslen ved Frederik Bajers Plads.

\section{"Mærket Afd. 2"}

Tilbage i Fiolstræde havde bibliotekets “ærværdige Bogsal” ifølge Høyer ikke "lignet sig selv ret meget i de sidste Par Maaneder", og, tilføjede han: "Tre Damer svinger Kautschukstempler" i alle de bøger, der skulle flyttes med "Mærket Afd. 2". Damerne rykkede frem gennem de syv rækker af bøger og tidsskrifter i "hurtigt Tempo" 


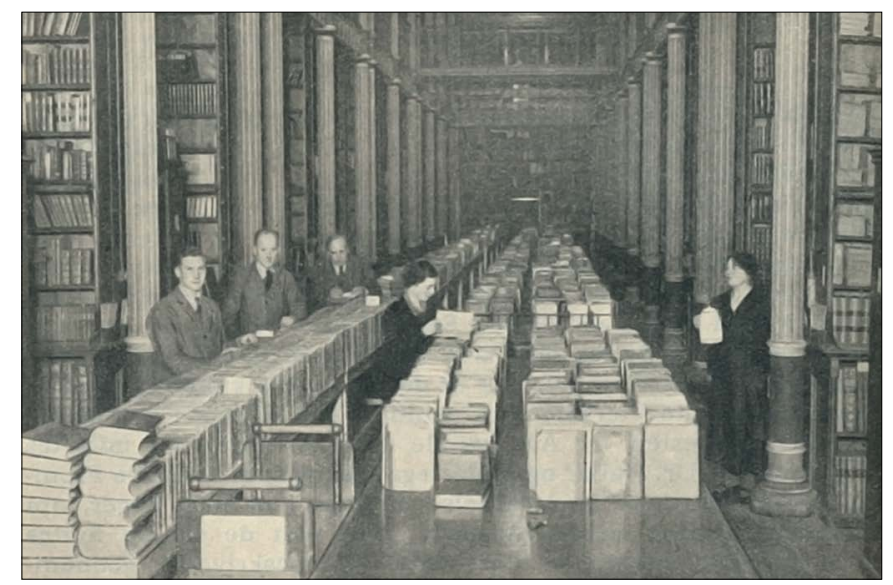

Bøgerne er linet op $i$ det gamle universitetsbibliotek i Fiolstrede, klar til sortering og markning. Illustration fra Bogens Verden, 1938.

med stemplerne, mens andre udtog tidsskrifter "efter de alfabetisk ordnede Sedler". Pladsen var trang, og montrer og borde blev hurtigt fyldt, men problemet mindskedes efterhånden som "al tom Reolplads" kunne tages "i Brug til dette Formaal.” Den meget deltaljerede og levende skildring af flytningen gav samtidig et indblik i tonen og stemningen under arbejdet, og Høyer berettede herom:

"Gennem Salen ruller hvert Øjeblik et par fyldte Bogvogne, der bringer Bøger eller tidsskrifter hen til Gulvet foran Skuret, hvor de stilles paa Plads efter en Række allerede ankomne vogne, og saa gaar det tilbage med et Par tømte Vogne, der paany skal fyldes. Trods al Travlhed bliver der Tid til Skæmt og Latter og sommetider til Returkørsel med en Dame paa Vognen. Naar Tidsskrifterne er bragt til Skuret, kommer turen til Bøgerne efter 1900, og derefter til de Bøger, der skal pilles ud af de tilbageblivende Afdelinger, og mens dette Arbejde staar paa, bringes Bøgerne før 1900 til Skuret direkte fra Hylderne."

Bibliotekar Luplau Jannsen ledte og overvågede arbejdet med at få bøger fra bogvognene "langet op til en Mand i Skuret, hvor de anbringes paa et Bord under Vinduet", for derpå at blive "klappet sammen og, naturligvis med fornøden Forsigtighed, banket ud af det aabne vindue og børstet af, saa alt Støv kommer ud af dem, og i ren Tilstand afleveredes de til en af Flyttefirmaets Folk, som pakker dem i trækasser (almindelige Flyttekasser), der er forede med Aviser." Kasserne rummede "ca. $13 / 4 \mathrm{~m}$ Oktaver" (dvs. bøger i oktavformat = små bøger), og når hver kasse var fyldt, fik den "et Lag Aviser over sig”, og blev forsynet med "en Træplade med Løbenummer og Angivelse af Etage i Bogtaarnet", hvorefter den var "klar til Afgang". Gennemsnitligt blev der pakket 140 kasser daglig. Flyttefirmaets "Motorvogne med Pahængsvogn med tomme Kasser” sørgede herefter for transporten med fyldte kasser ud til Nørre Allé, hvilket også fremgår af reportagefilmen, som rummer nogle fine optagelser af hele det imponerende sceneri.

Med nutidens trafikforhold in mente er Høyers bemærkninger om kørslen i indre by tankevækkende, thi: "At faa den 


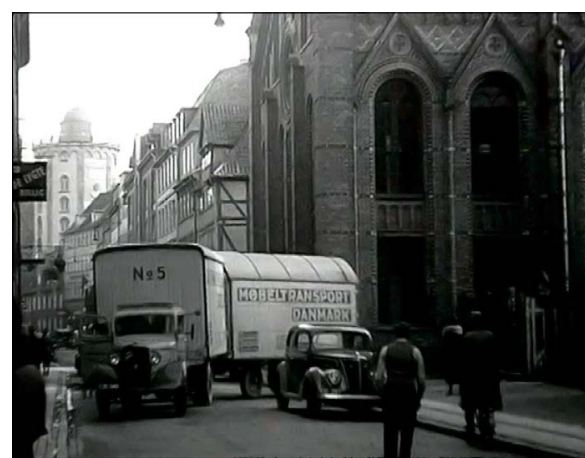

Flyttebilen svinger ud i Krystalgade. Stillbillede fra reportagefilmen.

fyldte Vogn ud i Krystalgade er et Kunststykke; navnlig i Dagene før Jul var gaden saa tilstoppet af parkerede og kørende Biler, Cykler og Trækvogne, at Politiet flere Gange maatte tilkaldes for at skaffe Passage. Den, der jævnlig som "Chaufførens Ven” kørte med ud til det nye Hus, krummede ofte Tæerne i Forventning om et uundgaaeligt Sammenstød, men altid gled vi igennem, mens Chaufføren lod falde en Bemærkning om, at "her er saamænd god Plads", men han saa afgjort meget lettet ud, naar han havde faaet sit Vogntog navigeret ud i den mere farbare Nørregade, og hans Ledsager, der havde siddet med Livet i Hænderne, satte det atter paa Plads."

I det nye bibliotek i Nørre Allé kørte vognen så "hen til Bogtaarnets Bagside" og med en elevator fragtedes bogkasserne til de respektive etager, hvor "Bibliotekar Birket-Smith ${ }^{7}$ og hans Stab stod parat" for at tømme kasserne og "stille Bøgerne op paa de nylakerede Staalhylder med rigelig Plads til tyve Aars Tilvækst." Den øverste 10. etage var således reserveret "til de fra ikke-flyttede Afdelinger udtagne Bøger samt til Dubletter o.lign."

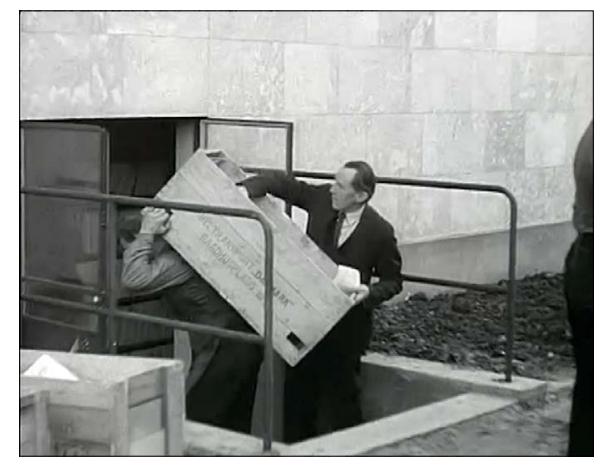

Indbering i bogtairnet. Still-billede fra reportagefilmen.

\section{Pladsproblemet}

Netop det helt centrale spørgsmål om de fremtidige pladsforhold i det nye bibliotek blev taget i op interviewet i Pressens Radioavis. Intervieweren, Bent Demer, spurgte overbibliotekaren om, hvorvidt der ville "være Plads nok i Taarnet", og fik hertil følgende svar: "Det kan ingen sige noget sikkert om; det afhænger af, hvor stor en Tilvækst vi faar i Aarernes Løb, og det kan variere meget. Men Taarnet er indrettet saadan, at det let kan forhøjes med indtil 5 Etager; det sker dog næppe i min Levetid."

Sidst i interviewet udtrykte Dahl sin egen og personalets glæde ved at tage det nye bibliotek i brug, så snart flytningen var overstået. Den havde imidlertid "slet ikke været den ubehagelige Oplevelse, man maaske paa Forhaand kunde have ventet, hvor det drejer sig om en Flytning med saa mange særlige Vanskeligheder, og den oven i købet fandt Sted midt i Vinterens Hjerte." Vintervejret havde ikke drillet, og "alt var gaaet glat".

Derfor var der også god grund til at rose personalet. Ifølge deres overbibliotekar havde det været "en Fornøjelse at 
se den Iver og Interesse, som har besjælet hele Bibliotekets Stab fra den ældste Bibliotekar til den yngste Medhjælper", og - tilføjede Dahl: "Det er jo en Oplevelse, som kun med flere Generationers Mellemrum falder i Biblioteksfolks Lod at være med til, og der har ogsaa været en særegen Stemning over vor Tilværelse i denne Tid." Samarbejdet med flyttefolkene havde også fungeret upåklageligt. Flyttefirmaet burde egentlig nævnes ved navn, mente Dahl, men det var jo "forbudt at reklamere i Radioen". Det var gået som "en Leg", hvilket måske også kunne forklares med et lille, men ikke ueffent personalegode, som overbibliotekaren godt syntes han kunne reklamere for, nemlig hans "yndlingsdrik, Kaffen", for: "ved en Vinterflytning er Kaffen en uvurderlig Stimulans, og det er ikke noget lille Antal Kopper varm Kaffe, der er sat til Livs hver Dag, men jeg regner Udgiften til dem for ualmindelig velanvendt."

Alt i alt vurderede Dahl overfor intervieweren, at flytningen var "gaaet saa godt, som jeg kunde ønske”, og tilføjede, at han især glædede sig til, "at vi nu snart kan tage vores nye Hus i Besiddelse", som ville få stor betydning i fremtiden. Hans konklusion var ikke til at tage fejl af: "Mine Medarbejdere og jeg er taknemmelige over, at man har givet os dette smukke og - jeg tror, man tør sige - praktiske Hus at arbejde i, og jeg haaber, at vort Publikum snart skal komme til at mærke det Fremskridt, som det nye Bibliotek vil betyde. Vi faar her Mulighed for at yde Lægevidenskabens og Naturvidenskabernes Dyrkere en adskilligt bedre og mere effektiv biblioteksmæssig Betjening end tidligere, og der er ikke noget, mine medarbejdere og jeg hellere ønsker."

\section{Flytningens sidste fase} Inden flytningen var tilvejebragt, men så betids, at der kunne foretages ændringer og justeringer, udarbejdede Svend Dahl den 24. januar 1938 en instruks til personalet om tiden fra "Dagen efter Flytningens Ophør" og frem til genåbningen af Universitetsbibliotekets nu 1. afdeling i Fiolstræde og 2. afdeling på Nørre Fælled, som skulle finde sted den 10. februar. Når flytningen var overstået ville der "blive Fridag", og - anførte Dahl videre; "derefter vil Tjenesten til og med d. 7. Februar fordele sig" efter listen i instruksen med angivelse af, hvad de 33 medarbejdere skulle påtage sig i de nu to afdelinger af Universitetsbiblioteket. Den 8. februar kl. 16 ville der blive afholdt "en Reception (Formiddagsdragt)" i det nye biblioteks studenterlæsesal for særligt indbudte gæster, og overbibliotekaren bad i sin instruks personalet om at være til stede. Dagen derpå, den 9. februar, ville der "være Tjeneste Kl. 10-13, for at de sidste Forberedelser kan træffes til Aabningen af de to Afdelinger" for publikum den 10. februar.

Der var mange fordele ved udskillelsen af den del af bogmassen fra Universitetsbiblioteket i Fiolstræde, der skulle flyttes ud til det nye bibliotek. En tiltrængt revision af bibliotekets bestand blev samtidig foretaget i forhold til hyldelisterne og katalogerne, og dermed skabtes et overblik over de bøger og tidsskrifter, som måtte være bortkommet eller gået tabt $\mathrm{i}$ årenes løb. Samtidig blev det nye bibliotek også ordnet og indrettet efter helt nye principper ud fra ønsket om at gøre adgangen til information så let som overhovedet muligt ud fra de givne økonomiske rammer.

Efter at arbejdet var tilendebragt, gjorde Høyer status og drog følgende lære af flytningens forløb: 


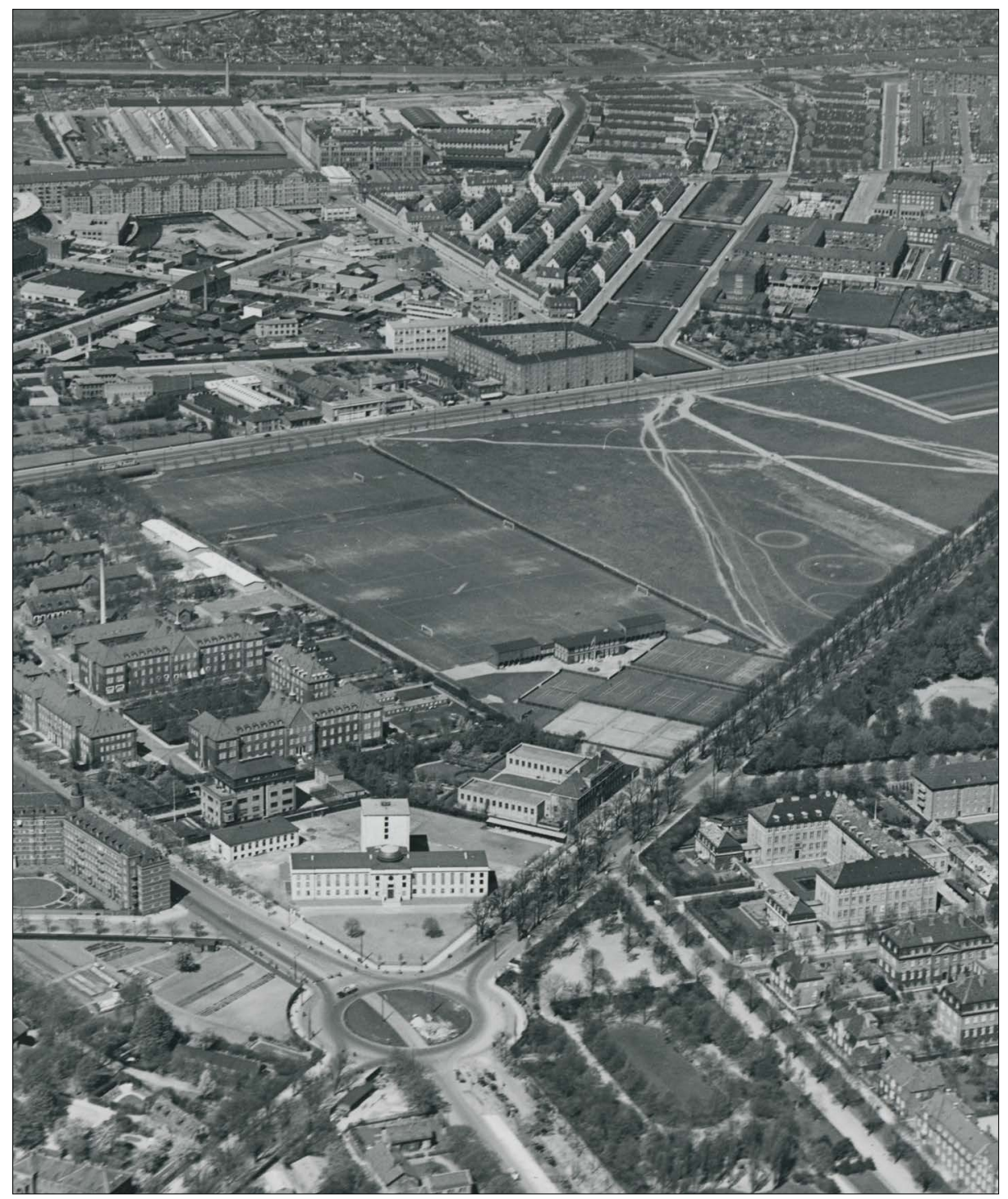

Luftfoto af et meget nogent bibliotek foran Norre Falled, som i 1938 stadig er en bar mark. Optagelse affirmaet Aero Express. Det Kongelige Bibliotek, Luftfotosamlingen.

"At flytte et Bibliotek af større Omfang er aldrig let. Men det er værre at flytte et halvt end et helt, og værst, naar Bøgerne yderligere skal opstilles efter nye Principper før Flytningen."
Alligevel kunne Universitetsbibliotekets ledelse se tilbage på en flytning, som ifølge Høyer var "gaaet programmæssigt, med al ønskelig Hurtighed og Omhu uden Gnidninger af nogen Art", hvilket 
også måtte tilskrives "den Iver og det gode Humør og Kammeratskab, hvormed samtlige "Flyttedamer og -mænd", baade Bibliotekets egne og Flytteforretningens, er gaaet løs paa deres Opgaver."

Indvielsen af det nye universitetsbibliotek I sin omtale i Bogens Verden umiddelbart efter indvielsen fremhævede den daværende biblioteksinspektør i Statens Bibliotekstilsyn, Robert L. Hansen, den rolle som især overbibliotekar Svend Dahl havde spillet gennem adskillige år. Han havde "med stor Energi ført dette Byggeforetagende til Ende" med støtte fra "Regering og Rigsdag", og Robert L. Hansen tilføjede, at "Overbibliotekarens Ønsker om en Bygning, der gav det naturvidenskabelige Biblioteksvæsen den Plads, der tilkommer det i vor Tid" dermed var blevet imødekommet.

Den 8. februar 1938 afholdtes en stor reception i det nye og storslåede bibliotek. Studenterlæsesalen blev om eftermiddagen godt fyldt op af indbudte gæster, deriblandt nobelpristageren, professor Niels Bohr og hans bror, professor Harald Bohr. Også nobelpristageren August Krogh var indbudt, men han takkede imidlertid nej til at deltage, da han befandt sig "meget ilde ved officielle festligheder". Derimod ville han "gærne se over en dag", når det passede Svend Dahl, "bl.a. for at tale om de arrangementer som vel bør træffes mellem Universitetsbiblioteket og institutbibliotekerne i nærheden."

Ifølge Robert L. Hansen fandt indvielsen sted "under yderst beskedne, man tør vel næsten sige for beskedne Omstændigheder: Det var jo dog faktisk en Begivenhed af saa sjælden Natur, at man turde have omgivet den med en passende Festivitas. Men Tiderne er jo nu engang strænge." Helt ufestligt var det dog ikke, idet der var bundet en musikalsk sløjfe om hele arrangementet. Ingerslev-trioen ${ }^{10}$ diverterede med allegroen fra P. Heises trio i Es-dur, og Studentersangforeningen sang en kantate til lejligheden skrevet af én af de ansatte ved Universitetsbiblioteket, som i øvrigt havde begået flere kantater, bibliotekar Carl Dumreicher. I kantatens anden sats sang solostemmer fra Studentersangforeningen "Medicinens, Kemiens, Zoologiens, Matematikkens og Astronomiens Pris."

Indvielseshøjtideligheden indledtes med en velkomst, hvori overbibliotekar Svend Dahl ifølge Robert L. Hansen "pointerede, at man ikke siden 1657 havde fejret en lignende Begivenhed, nemlig da Universitetsbibliotekets Lokaler paa Trinitatis Kirkeloft blev indviet", og overbibliotekaren tilføjede: "Da Herholdts Bygning i Fiolstræde var færdig i 1861, fandt ingen Indvielse Sted, idet det drejede sig om en Nybygning, Universitetet havde opført for sine egne Penge."

Der blev holdt flere officielle taler. Departementschef Frederik Graae, der havde været formand for Byggeudvalget, "afleverede" ifølge biblioteksinspektørens referat bygningen "formelt til Undervisningsministeren”, Jørgen Jørgensen, der i sin tale "dvælede ved Bogens Betydning for den folkelige Kultur og for Sammenhængen mellem Slægterne, og sluttede "med at indvi Bygningen og med Ønsket om, at den maatte tjene Videnskab og Kultur til Gavn for det danske Folk.” Også Københavns Universitets rektor, professor dr.med. Carl Bloch, som havde været en ivrig fortaler for opførelsen af det nye bibliotek, hæftede sig ved "det overordentlige Fremskridt, der her er sket til Fordel for Naturvidenskabens Dyrkere" og takkede Svend Dahl 
Svend Dabl bag sit skrivebord i overbibliotekarens nye kontor på Norre Allé. Personen til venstre er ikke identificeret.

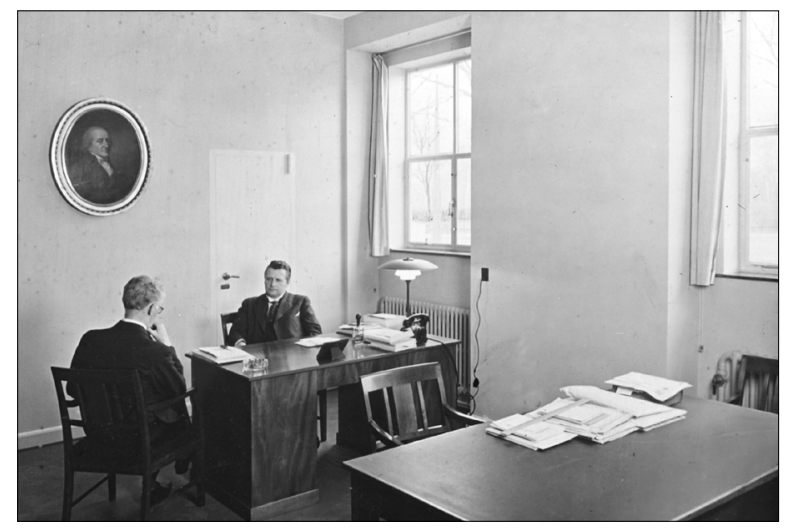

med ordene: "det er en Lykke for dansk Videnskab, at vi netop paa dette Tidspunkt har haft en Mand som Overbibliotekar Dahl”. Ifølge biblioteksinspektøren havde rektor endvidere i "nogle Slutbemærkninger" understreget, at "denne Nybygning vidner om et demokratisk Lands Forståelse af Videnskabens Betydning og bød i øvrigt det nye Bibliotek Velkommen fra mange medicinske Læreanstalter og Institutioner i dens Nabolag." Naturligvis blev der også overbragt lykønskninger fra henholdsvis Det Kongelige Biblioteks overbibliotekar, Carl S. Petersen og Emanuel Sejr fra Statsbiblioteket i Aarhus. Desuden modtog overbibliotekar Svend Dahl en række gaver, legater, pengebeløb og boggaver fra forskellig side.

Efter indvielseshøjtideligheden, der blev rundet af med korsang, nød de forsamlede gæster ifølge Robert L. Hansen "et Glas Portvin på det nye Biblioteks Velgaaende for endelig at foretage en Vandring gennem Bibliotekets mange Rum under Vejledning af Bibliotekspersonalet". ${ }^{11}$

\section{Afslutning}

Efter mange års indsats og en veloverstået flytning af en imponerende bogmasse kunne Universitetsbibliotekets 2. Afde- ling som planlagt åbne for publikum den 10. februar 1938, og som det udtryktes af overbibliotekar Svend Dahl og bibliotekar Alfred Høyer i deres førnævnte beretning i Bogens Verden i 1938 om Universitetsbibliotekets flytning sende "en Venlig Tanke" til "Vejrguderne", thi "de Gêner, der har været ved at foretage Flytningen midt i Vinterens Hjerte, har været minimale."

Der var tale om en bedrift, da udskillelsen og flytningen fandt sted, og samtidig havde Svend Dahl og kredsen omkring ham af sagkyndige og rådgivere, herunder byggeudvalget, efter bedste skøn søgt at tage højde for, at behovet for plads åbenbart ikke i de nærmeste årtier inden for naturvidenskaberne og medicinen ville blive mindsket, snarere tværtimod. Der var i planlægningen taget højde for en tilvækst, der betød, at der kunne være plads til yderligere godt 200.000 bind, eller målt i hyldemeter, yderligere $6-7 \mathrm{~km}$ bøger og tidsskrifter. For sidstnævntes område regnedes med, at bibliotekets bestand skulle kunne udvides med godt 150 $\%$ i årene fremover. Det forklarer også, hvorfor der var planlagt en mulighed for, at det nye biblioteks bogtårn kunne forøges med fem etager. 
Delingen af Universitetsbiblioteket $i$ to afdelinger blev også omtalt af Svend Dahl, da han på Danmarks Biblioteksforenings årsmøde i august 1938 aflagde "Aarsberetning om de faglige og videnskabelige Biblioteker". Hele den store indsats, der var ydet fra manges side med hensyn til realiseringen af tanken om delingen og opførelsen af Universitetsbibliotekets 2. Afdeling på Nørre Allé, rammes på smukkeste vis ind med Dahls kommentar hertil: "Det er en hel Metamorfose, der er ved at foregaa med Universitetsbiblioteket: en saa gennemgribende Omlægning af et stort Bibliotek som den, der her er i Gang og nu om faa Aar kan ventes fuldbyrdet,

\section{Noter}

1 Jf. utrykt kildemateriale i Rigsarkivet: Københavns Universitet, Universitetsbiblioteket. Byggesagen. Løbenr. 26. Flytningen mm. \& Løbenr. 28. Planer for udvidelse, UB2 december $1944 \mathrm{~mm}$. Hvor intet andet anføres $i$ artiklen baseres dens oplysninger på arkivalier fundet $\mathrm{i}$ ovennævnte arkivsager; i Statens Filmarkiv findes originaloptagelsen: $7 \mathrm{~km}$. Bøger flyttes. Dansk Film Revy 1938. - Vedr. Universitetsbibliotekets 2. afd. og dets historie i almindelighed, jf:: Svend Dahl: "Om en medicinsk-naturvidenskabelig Biblioteksbygning paa Nørre Fælled”, Arkitekten, 1931, s. 117-121; Svend Dahl: Universitetsbibliotekets nye bygning. 1938, s. 13; Torsten Schlichtkrull: “Københavns Universitetsbibliotek - 524 år og i støbeskeen", Bogens Verden 3:2006, s. 13-23; Torsten Schlichtkrull: "75 år på Nørre Allé, Brugernes muligheder", Magasin fra Det Kongelige bibliotek, 25:4, 2012, s. 19 41.

2 Svend Dahl \& Alfred Høyer: "Universitetsbibliotekets Flytning”, Bogens Verden, 1938, s. 1-5.

3 Ibid. er næppe sket ret mange andre Steder i Verden, om overhovedet nogetsteds". ${ }^{12}$

Historien om udskillelsen og flytningen af den naturvidenskabelige og medicinske litteratur fra Universitetsbiblioteket i Fiolstræde og indvielsen af det nye bibliotek på Nørre Fælled er også et vidnesbyrd om, hvor vigtigt det er at have indsigt $\mathrm{i}$ beregning, håndtering og styring af mange informationer af vidt forskellig karakter, dvs. i logistik. Det var forudsætningen for, at operationen lykkedes, og det endog mange år før, at begreber inden for moderne virksomhedsledelse, som f.eks. "supply chain management" blev moderne. ${ }^{13}$

4 Carl Dumreicher (1879-1965), bibliotekar og forfatter.

5 Bodil Schmidt-Nielsen: August og Marie Krogh. Et falles liv for videnskaben. 1997, s. 181.

6 Jf. note 2

7 Frederik Birket-Smith, bibliotekar og guitarist, søn af Universitetsbibliotekets fhv. leder, Sophus Birket-Smith (1838-1919).

8 Ibid.

9 Ibid.

10 Sverre Forchhammer (violin), Alberto Medici (cello) og Poul Ingerslev-Jensen (klaver).

11 Robert L. Hansen: "Det nye Universitetsbibliotek”, Bogens Verden 1938s. 53-63

12 Svend Dahl: "Aarsberetning om de faglige og videnskabelige Biblioteker. Aarsmødet 1938", Bogens Verden 1938, s. 218-225.

13 Bibliotekar Oscar Rishede, DR Arkiv; Arkivar og konservator Karin Bonde Johansen, Det Danske Filminstitut Filmarkivet; bibliotekskonsulent Torsten Schlichtkrull, Det Kongelige Bibliotek og fhv. postinspektør Gunnar Thornfeldt takkes for hjælp og bistand i forbindelse med udarbejdelse af denne artikel. 